\title{
Private Enforcement of the Kansas Wage Payment Act
}

\author{
Joseph A. Schremmer \\ Sean M. McGivern ${ }^{* *}$ \\ No man is above the law and no man is below it .... \\ -Theodore Roosevelt ${ }^{1}$
}

\section{INTRODUCTION}

We are practitioners, and in our practice we meet with many prospective clients who have worked, for a wage, but have not been paid by their employers. Unfortunately, there is nothing we as private lawyers can do for a majority of these people. The problem is not that the law provides no relief. Kansas, in fact, has a set of statutes on the books that makes it illegal for employers to fail to pay their wage-earning employees and penalizes violators. These laws, known as the Kansas Wage Payment Act (KWPA or Act), however, are not adequately enforced. For this reason, we argue here, the law should incentivize private enforcement. The most effective means of doing so is to amend the KWPA to include an attorney fee shift that favors prevailing plaintiffs, i.e., prevailing employees.

In the status quo, the KWPA provides for two mechanisms of enforcement. First, the state of Kansas, through the Kansas Department of Labor (KDOL), is authorized to investigate and adjudicate employee wage complaints administratively. Second, the KWPA provides a private cause action for individual employees who are aggrieved under the Act. Even together these enforcement mechanisms have proved unable to vindicate a substantial number of Kansas employees victimized by wage theft. The

\footnotetext{
${ }^{*}$ Associate, Withers, Gough, Pike, Pfaff \& Peterson, LLC, in Wichita, Kansas. J.D., University of Kansas School of Law, 2013.

** Partner, Withers, Gough, Pike, Pfaff \& Peterson, LLC, in Wichita, Kansas. J.D., University of Kansas School of Law, 2006. The authors thank Donald N. Peterson, II for his mentorship and encouragement, generally.

1. President's Message at the Opening of the Second Session of the Fifty-Eighth Congress, Dec. 7, 1903, in 1 The Roosevelt Policy: Speeches, Letters and State Papers, Relating to Corporate Wealth and Closely Allied Topics 191, 196 (William Griffith ed., 1919).
} 
problem with the administrative enforcement mechanism is that it is underutilized. The KDOL simply does not investigate and prosecute a significant number of wage complaints. Because the right to an administrative hearing depends on the agency's initial determination that an actual dispute exists, the agency tends to refer complainants to private lawyers.

Private enforcement is also problematic in the status quo. Wage payment claims are typically small, ranging from miniscule to modest in most cases. Rarely is a claim worth more than a few thousand dollars. As a consequence, the costs of prosecuting a lawsuit to recover the owed wages and penalties quickly add up to more than the total potential recovery. The chief driver of legal costs, of course, is attorney fees. Because aggrieved employees are, by definition, wage earners who have not been paid their wages, virtually all wage payment cases are taken on a contingency fee basis. Lawyers have no economic incentive to take cases on contingency when the total potential recovery is likely to be less than the lawyer's fees. Lawyers, therefore, have no economic incentive to take a large portion of wage payment cases, and the KWPA is poorly enforced as a result.

Two recent examples from our practice illustrate this problem. Within about one month's time, we had two prospective clients call our office with potential wage payment claims. Client $\mathrm{A}$ had been fired from his job and not paid all of his earned wages by his former employer. Client A had a written employment contract with his employer that permitted the prevailing party in any dispute over the contract to recover his reasonable attorney fee. Client B had left his job and was also owed wages in comparable amounts to Client A. Client B, unlike A, was an at-will employee with no written employment contract and no attorney fee shift. We could afford to take Client A's case because of the potential for fee recovery. We had to decline B's case.

Client A and Client B were similarly situated in every way except the fee shift. Each had been taken advantage of in the same way and for nearly the same amount of money. Yet redress was possible only for one. As to the other, the KWPA went unenforced. This is a problem with the law.

But lawyers are creative. For every prospective client like Client B whose wage payment case we have declined, there is a Client $\mathrm{C}$ for whom we have tried, sometimes vainly, to seek relief under a different, less applicable statute that allows for attorney fee recovery (often the federal Fair Labor Standards Act (FLSA)). There is little sense in stretching the facts of a case to fit a mostly inapposite law when there is a law directly on point. Yet this is what lawyers across the state are forced to attempt when approached with a legitimate but unenforceable wage payment claim. 
The argument of this article is that there should be greater private enforcement of the KWPA, and that this goal can be achieved by amending the KWPA to include an attorney fee shifting provision that awards prevailing plaintiffs their reasonable attorney fee. A fee shift is necessary for three reasons. First, without a fee shift, deserving employees are unfairly barred from enforcing their wage payment claims in court. Second, an attorney fee shift is necessary to give meaning to the rights granted by the KWPA, which are rendered hollow by the lack of enforcement under the present system. And third, deputizing individual employees to enforce the KWPA privately would not only improve enforcement, but would do so at the expense of the violators of the law rather than the expense of the State of Kansas.

This article proceeds in four parts. In Part II, we discuss the history and public policy underlying the KWPA and briefly explain the operation of the law, including the administrative enforcement mechanism. In Part III, we synthesize the literature on the rationales for and effects on litigation of attorney fee shifts. We pay particular attention to the private attorney general doctrine, developed by the United States Supreme Court in connection with the Civil Rights Act and adopted by Kansas courts in various contexts. In Part IV, we set forth the types of fee shifts found in the wage payment and collection statutes of other states as part of a survey of all fifty states and the District of Columbia. Part IV shows that Kansas is in a small minority as a state with a comprehensive wage payment and collection law without an attorney fee shift. Part V sets forth our argument for why, in light of the purpose and public policy of the KWPA, as well as the theoretical and practical reasons for attorney fee shifts, the KWPA should be amended to include an attorney fee provision. In Part V, we propose specific language for the attorney fee shift. We conclude in Part VI.

\section{THE History, PURPose, AND CURRENT StATUS OF THE KANSAS WAGE PAYMENT ACT}

Kansas attorneys receive calls almost daily from people who want to pursue wages unfairly withheld, deducted, or never paid by their employers. In most instances, the amount in controversy is small-ranging from $\$ 20$ to $\$ 2,000$. Such modest amounts are generally insufficient to justify a contingency fee based representation, especially in the typical case when the employer possesses most of the relevant documents. And because the disputed funds are wages, a retainer or hourly fee arrangement is out of the question.

These concerns motivated the Kansas Legislature in 1973 to pass the 
Kansas Wage Payment Act. ${ }^{2}$ At the time, Kansas was "near the bottom among most states insofar as the existence of any effective remedies for employed persons in the employer-employee relationship." 3 Only $40 \%$ of the individuals employed in Kansas could claim the minimum wage protections of the Fair Labor Standards Act (FLSA). ${ }^{4}$ Moreover, to the extent that a "prompt payment" requirement is read into the FLSA, such a requirement only applies to the statutory minimum wage and not generally to all earned wages due. ${ }^{5}$

In the early 1970s, the Kansas Attorney General's office regularly received calls about withheld wages. Such claims "were usually small and therefor [sic] the complainants couldn't afford an attorney. There was nothing [the Kansas Attorney General's] office could do, and this legislation was needed." Sample grievances included a 7-Eleven store in Emporia that docked an employee's pay for returned customer checks, and a restaurant that withheld shortages from the pay of all employees who had access to the cash register during the relevant shift. ${ }^{7}$ House Member T. McCune likened employer withholdings to unlawful garnishments. ${ }^{8}$ That was no small concern at the time, as the United States Supreme Court had just struck down a Wisconsin prejudgment garnishment statute in 1969.9 The Court said such a prejudgment garnishment "may as a practical matter drive a wageearning family to the wall.",10

Practices like these contravene "the most basic precept of employeremployee relations, [which] is that employees be paid their earned wages, in full, in money, and without delay."11 To this end, the KWPA provides, as its overarching principal, that employers must timely "pay all wages due" to

2. Kansas Wage Payment Act, KAN. Stat. AnN. $§ \S 44-301$ to 44-340 (West 2014).

3. An Act Providing for Wage Payment and Collection: Hearing on H.B. 1429 Before H. Comm. On Labor \& Industry, 1973 Leg., 68th Sess. 2 (Kan. 1973) (statement of T. McCune, Member, House of Representatives).

4. Id. at 1 .

5. See, e.g., Craig Becker, The Check Is in the Mail: Timely Payment Under the Fair Labor Standards Act, 40 UCLA L. REV. 1241, 1250 (1993).

6. An Act Providing for Wage Payment and Collection: Hearing on H.B. 1429 Before H. Comm. On Labor \& Industry, 1973 Leg., 68th Sess. i (Kan. 1973) (statement of Jerry Finnell, Attorney General's Office).

7. Id. at 6 (statement of T. McCune, Member, House of Representatives).

8. Id. at 2 .

9. Id. (citing Sniadach v. Family Fin. Corp. of Bay View, 395 U.S. 337 (1969)).

10. Sniadach v. Family Fin. Corp. of Bay View, 395 U.S. 337, 341-42 (1969).

11. An Act Providing for Wage Payment and Collection: Hearing on H.B. 1429 Before H. Comm. On Labor \& Industry, 1973 Leg., 68th Sess. 2 (Kan. 1973) (statement of T. McCune, Member, House of Representatives). 
employees, and that employers may not "withhold, deduct, or divert any portion of an employee's wages" except for limited, approved reasons. ${ }^{12}$ For willful violations, the KWPA imposes a penalty of $1 \%$ per day for late payment, up to $100 \%$ of the unpaid wage. ${ }^{13}$ Put more simply, an employer that willfully fails to pay an employee all earned wages due is liable to the employee for up to twice the amount of the owed wages.

Although the specifics of how the KWPA operates and has been interpreted exceed the scope of our analysis here, ${ }^{14}$ it will help to summarize the key provisions of the law. They are as follows:

- "Wages" are defined as compensation for labor or services rendered by an employee, whether the amount is determined on a time, task, piece, commission or other basis, less authorized withholding and deductions. ${ }^{15}$ The regulations add that the term includes all agreed compensation for services for which the conditions required for entitlement, eligibility, accrual, or earning have been met by the employee. ${ }^{16}$

- Employers must pay employees "all wages due" at least once a month, on regular paydays designated in advance by the employer. ${ }^{17}$

- In the event of disputes about wages owed, employers must pay all undisputed wages and fight about only the disputed portion. $^{18}$

- The law defines permissible and impermissible deductions from employees' compensation. ${ }^{19}$ The most frequently litigated issue here is whether the deductions are authorized by the employee, in writing, "for a lawful purpose accruing to the benefit of the employee." 20

- The KWPA imposes personal liability on officers and agents of

\footnotetext{
12. KAN. STAT. ANN. §§ 44-314(a), 44-319(a) (West 2014).

13. Id. $\$ 44-315(\mathrm{~b})$.

14. For a thorough and well-done primer on the KWPA, see generally Boyd A. Byers \& Carolyn L. Rumfelt, See Dick and Jane Work: A Kansas Wage Payment Act Primer, KAN. J. B.A., Oct. 2003, at 14.

15. KAN. StAT. ANN. § 44-313(c) (West 2014).

16. KAN. ADMIN. REGS. $\S 49-20-1(\mathrm{~d})$. This includes profit-sharing compensation. Id.

17. KAN. STAT. ANN. § 44-314(a) (West 2014).

18. Id. § 44-316(a).

19. Id. $\S 44-319$. Section 44-319 was recently amended to clarify that certain withholdings are permissible, including withholdings for unreturned merchandise or uniforms, when supported by a written agreement. $I d$.
}

20. Id. § 44-319(a)(3). 
the employer who knowingly allow the employer to violate the law. ${ }^{21}$

Kansas courts have often noted the uncommon strength of the public policy supporting the KWPA. In Coma Corp. v. Kansas Department of Labor, the Kansas Supreme Court reaffirmed "the strong and longtime Kansas public policy of protecting wages and wage earners." 22 The Coma Corp. court went on to set forth a bit of the history of Kansas's public policy regarding wages:

[T] hroughout the history of this state, the protection of wages and wage earners has been a principal objective of many of our laws. See, for example, K.S.A. $60-2307$, originally enacted as G.S. 1868 , ch. 38 , § 6, providing that otherwise exempt personal property shall not be exempt from attachment or execution for wages; K.S.A. 44-312, enacted in 1901, giving preference to the payment of wages in the case of receiverships or assignments for the benefit of creditors; the statute restricting garnishment of wages, K.S.A. 60-2310, which reflects the rationale of G.S. 1868 , ch. $80, \S 490$; and the wage payment act, K.S.A. 44-313 et seq., enacted in 1973. K.S.A. 40-3103, like the statutes mentioned above, gives preference to wage earners, in order that they and the families dependent upon them are not destitute. ${ }^{23}$

In addition to the strict remedies under the KWPA, certain other provisions illustrate the importance of the policy behind the law. No right under the KWPA can be contravened, set aside, or waived unless it is raised in court or administrative proceedings of the KDOL. ${ }^{24}$ Accordingly, an employer cannot require an employee to sign a release to receive wages; such a release is null and void. ${ }^{25}$ In a recent opinion, the United States District Court for the District of Kansas held that a previous FLSA collective action settlement was legally incapable of compromising the KWPA claims of identical class members. ${ }^{26}$ The KWPA's coverage even extends to

21. Id. § 44-323(b); Traffas v. Bridge Capital Investors II, No. CIV. A. 90-1304 MLB, 1993 WL 339293 (D. Kan. Aug. 23, 1993) aff'd sub nom. Traffas v. Bridge Capital Corp., 46 F.3d 1152 (10th Cir. 1995); State ex rel. McCain v. Erdman, 607 P.2d 78 (Kan. Ct. App. 1980).

22. 154 P.3d 1080, 1092 (Kan. 2007); see also A.O. Smith Corp. v. Kan. Dep’t of Human Res., 144 P.3d 760 (Kan. Ct. App. 2005).

23. Coma Corp., 154 P.3d at 1092 (quoting Burriss v. N. Assurance Co. of Am., 691 P.2d 10, 16 (Kan. 1984)).

24. KAN. STAT. ANN. §§ 44-321, 44-324(a), (b) (West 2014).

25. Id. § 44-316(b). The only exception that exists is for "binding settlement agreements," which are supervised by the KDOL. Id. § 44-316(b); KAN. ADMIN. REGS. § 49-20-1(c).

26. Allen v. Mill-Tel, Inc., No. 11-1143-EFM-KGS, 2012 WL 2872160 (D. Kan. July 12, 2012). 
undocumented immigrants. ${ }^{27}$ What is more, courts have recognized a tort claim to vindicate employees who are terminated in retaliation for exercising rights under the KWPA. ${ }^{28}$

The KWPA sets up an administrative process within the KDOL for employees to pursue remedies under the Act. ${ }^{29}$ Employees initiate the process by submitting written complaints on KDOL-prescribed forms. ${ }^{30}$ The KDOL affords claimants a hearing only after various prerequisites are met, including, importantly, an investigator's determination that an actual dispute exists. $^{31}$ The Office of Administrative Hearings conducts the hearings, and attorneys are allowed to participate. ${ }^{32}$ After a hearing, the presiding officer prepares written findings of fact and conclusions of law and awards appropriate damages and penalties. ${ }^{33}$ The presiding officer's order becomes final if not timely appealed to the Secretary of Labor. ${ }^{34}$ There is a mechanism for the Secretary of Labor to enforce wage orders for the benefit of the employee. ${ }^{35}$

The problem with the administrative process is that bureaucrats must consider individual rights alongside other, competing factors. ${ }^{36}$ Anecdotal evidence, collected in the course of the authors' practice and in preparation of this article, suggests the KDOL's mandate to enforce the KWPA is not being fulfilled. For example, the authors' firm regularly consults with prospective clients about wage payment and collection issues. Some of these individuals have worthy claims, and we refer them to the KDOL. They often call back after the KDOL determines there is a lack of evidence to pursue the case, or says there is no claim, or suggests that the person hire a private lawyer. But small individual cases, even when obviously

27. Coma Corp. v. Kan. Dep't of Labor, 154 P.3d 1080 (Kan. 2007).

28. Campbell v. Husky Hogs, L.L.C., 255 P.3d 1, 3 (Kan. 2011) (recognizing tort claim). But see Deeds v. Waddell \& Reed Inv. Mgmt. Co., 280 P.3d 786, 792 (Kan. Ct. App. 2012) (holding employee's complaints were too equivocal to invoke protections of the KWPA).

29. KAn. Stat. AnN. § 44-322a (West 2014).

30. KAN. ADMIN. REGS. § 49-21-1.

31. Id. $\S 49-21-2(\mathrm{~b})(8)$.

32. KAN. DeP'T LABOR, Kansas Wage Payment Act Hearing Procedure, http://www.dol.ks.gov/Laws/hearing.aspx (last visited May 11, 2014). See KAN. AdMIN. RegS. $\S 49-21-2$ for the applicable procedure.

33. KAn. Admin. RegS. § 49-21-3(d) (2004); KAn. Stat. ANN. § 44-322a(b) (West 2014).

34. See Kan. Stat. AnN. § 44-322a(b) (West 2014).

35. Id. § 44-324(b)-(d).

36. Elizabeth D. De Armond, A Dearth of Remedies, 113 PenN. ST. L. Rev. 1, 33 (2008) (describing the various concerns that motivate administrative agencies in enforcing private rights); Mark A. Cohen \& Paul H. Rubin, Private Enforcement of Public Policy, 3 YALE J. ON Reg. 167, 193 (1985) (explaining the inefficiency of agency enforcement). 
meritorious, make no sense for private lawyers to take without an attorney fee shift. The costs of prosecuting a small wage claim simply exceed the value of the claim, making the lawsuit uneconomic for the lawyer. In one particular situation from the authors' practice, the KDOL advised it would not take any additional cases against a particular employer because of the employer's risk of insolvency. ${ }^{37}$

Because it is uneconomic to bring small wage payment claims, current KWPA litigation predominately involves sizeable individual claims and large aggregations of relatively small claims. ${ }^{38}$ Individual employees with small, non-class claims for unpaid wages are left between a rock and a hard place. These individuals frequently lack the funds to hire a lawyer because their employer wrongfully withheld wages. And private lawyers have no incentive to take these cases on a contingency fee basis without an attorney fee shift. In most cases, there is no reason to pursue a representative action on their behalves. Meanwhile, the KDOL is apparently unable to bear the weight of enforcing the KWPA without the aid of private causes of action. The result is a law that courts claim is extremely important but that is very easy to break with impunity.

Many other states have solved this problem by providing for an award

37. This is not to suggest that the KDOL is unmotivated or lacking in good faith. That is not our opinion. Rather, the agency has its own prerogatives and cannot be expected to fill the roles of both advocate and judge. We believe the KDOL's efforts can be, and should be, supplemented by more private wage collection litigation to both ease the agency's burden and improve enforcement of the law.

38. See, e.g., Critchlow v. Barcas Field Servs., No. 13-CV-01404-JAR-KMH, 2014 WL 1664819 (D. Kan. Apr. 25, 2014) (alleging violations of the KWPA by failing to pay 5\% of net proceeds on a $\$ 47$ million sale of a company); Sibley v. Sprint Nextel Corp., 254 F.R.D. 662,669 (D. Kan. 2008) (certifying class claims of thousands of individuals to pursue underpaid commission claims).

Kansas federal courts have recently made aggregate actions for wage claims easier. In Garcia v. Tyson Foods, Inc., the District of Kansas permitted the plaintiffs to pursue a Rule 23 class action for unpaid wages under the KWPA based on principles under the FLSA relating to compensable time. Garcia v. Tyson Foods, Inc., 766 F. Supp. 2d 1167, 1187 (D. Kan. 2011) ("Thus, to the extent it is determined at trial that Tyson is required under the FLSA to compensate its employees for certain activities or time periods for which Tyson has not been compensating employees, then the KWPA class in this case may recover those amounts under the KWPA."). Garcia is significant because the representative action provisions of the FLSA require individual class members to provide written consent to join the case, whereas traditional Rule 23 actions include all defined class members until they opt out from the case. Brown v. Money Tree Mortg., Inc., 222 F.R.D. 676, 678-79 (D. Kan. 2004). As a result, plaintiffs can now vindicate FLSA rights through KWPA class actions brought under Fed. R. Civ. P. 23 or appropriate state counterparts such as K.S.A. \& 60-223. Since Garcia, the District of Kansas has expanded Garcia to state, categorically, that plaintiffs can rely on the FLSA as a legal basis for KWPA claims. Tarcha v. Rockhurst Univ. Continuing Educ. Ctr., Inc., No. CIV.A. 11-2487-KHV, 2012 WL 1998782, at *4 (D. Kan. June 4, 2012). 
of attorney fees to a prevailing employee in a wage action. ${ }^{39}$ Kansas has solved similar problems in other contexts by inserting attorney fee shifts into remedial statutory schemes. ${ }^{40}$ Oddly, the KWPA allows for recovery of attorney fees-but only for the KDOL. Private plaintiffs have no such attorney fee shift. ${ }^{41}$ As originally proposed in 1973, the KWPA contained a fee shift for prevailing plaintiffs. ${ }^{42}$ The provision was deleted in the first round of revisions, however, as a political necessity to secure support for passage of the bill. ${ }^{43}$

Passage of the bill was no small feat. In fact, organized labor had tried to introduce wage collection legislation in the six previous legislative sessions. ${ }^{44}$ Jim Parrish, a freshman Democrat member of the Kansas House of Representatives in 1972, reached out to the Kansas Association of Commerce and Industry (the antecedent to the Kansas Chamber of Commerce) to improve the bill's chances of passage. ${ }^{45}$ The bill passed the House of Representatives and was referred to two separate committees in the Senate, which is often considered the "kiss of death." 46 By making concessions, such as the attorney fee provision, however, Representative Parrish and his colleagues were able to eventually pass the bill.

\section{INTRODUCTION TO THE RATIONALES FOR AND EFFECTS OF ATTORNEY FEE SHIFTING IN LITIGATION}

A great deal has been written about whether, how, and why attorney fee shifting affects litigation. ${ }^{47}$ It is generally agreed that fee shifting in fact

\footnotetext{
39. See infra Part IV \& Appendix A.

40. See, e.g., Kansas Consumer Protection Act, Kan. Stat. AnN. § 50-643(e) (West 2014); Kansas Minimum Wage and Maximum Hours Law, KAN. STAT. ANN. § 44-1211 (West 2014); KAN. STAT. ANN. § 40-908 (West 2014) (making attorney fees available in certain insurance cases); KAN. STAT. ANN. § 60-2006 (West 2014) (attorneys fees taxed as costs in certain actions involving negligent motor vehicle operation); KAN. STAT. ANN. § 75-2973 (West 2014) (allowing state civil service board to award attorney fees for whistleblower act violations).

41. Id. § 44-324(c); Shelley v. Dep’t of Human Res., 723, 8 P.3d 33, 39 (Kan. Ct. App. 2000) (stating that prevailing individuals cannot recover attorney fees under the KWPA, but the government can).

42. H.B. 1429, 1973 Leg., 68th Sess. (Kan. 1973).

43. Interview with Jim Parrish, former Kansas Representative (May 3, 2014).

44. Id.

45. Letter from James W. Parrish to Boyd A. Byers \& Carolyn L. Rumfelt (October 30, 2003) (on file with author).

46. $I d$.

47. John J. Donohue III, Opting for the British Rule, Or if Posner and Shavell Can 't Remember the Coase Theorum, Who Will?, 104 HARV. L. REv. 1093, 1093 (1991) (noting the "immense literature analyzing this question" in 1991).
} 
influences parties' strategic litigation decisions. Far from a comprehensive literature review, the following attempts to synthesize and summarize relevant thought in the area of allocation of legal expenses. Specifically, the succeeding paragraphs introduce the concept of designing rules for allocating legal expenses to achieve desired levels of litigation as well as the most typical types of rules in existence.

\section{A. The Importance of Cost Allocation to Levels of Litigation}

The financial costs of litigation are significant. ${ }^{48}$ It is even possible, as Richard Posner points out, for parties' combined litigation expenditures to exceed the stakes of the litigation. ${ }^{49}$ Indeed, many of our courts' procedural rules can be understood as designed to allocate costs to increase the productivity of the parties' expenditures. ${ }^{50}$ It follows that the allocation of legal expenditures can influence the behaviors of parties and outcomes in litigation. ${ }^{51}$ Expense considerations are integral to parties' decision making in litigation, including decisions whether to bring suit and, if so, whether to settle or go to trial. ${ }^{52}$ As one commentator put it, in litigation, "cost considerations intrude with every move the attorney makes for his client."

Because allocation of legal expenses influences the decisions of litigants, different systems of expense allocation cause different levels of litigation. $^{54}$ In designing cost allocation rules (like attorney fee shifting rules) for an area of law, therefore, it is necessary first to determine whether and how the current level of litigation in the particular area should be changed. ${ }^{55}$ For instance, in areas of the law in which litigation is desirable, legal costs should be allocated to incentivize parties to litigate. ${ }^{56}$

One situation in which increased levels of litigation are desirable is where the expense of vindicating a right or entitlement is greater than many of the holders of the right can bear. In other words, it is desirable to increase litigation in areas in which potential plaintiffs lack access to legal remedies

48. Gideon Parchomovsky \& Alex Stein, The Relational Contingency of Rights, 98 VA. L. REV. 1313, 1338-39 (2012).

49. Richard A. POSNER, ECONOMIC ANALYSIS OF THE LAW $\S 21.10$, at 613 (7th ed. 2007).

50. Id. at 611 .

51. See generally Steven Shavell, Suit, Settlement, \& Trial: A Theoretical Analysis Under Alternative Methods for the Allocation of Legal Costs, 11 J. L. STUD. 55 (1982).

52. See generally id.

53. Neil J. Williams, Fee Shifting \& Public Interest Litigation, ABA J., June 1978, at 859, 860.

54. Shavell, supra note 51, at 71 .

55. Id.

56. Id. at 73 . 
because they lack sufficient liquid assets to pay the legal fees necessary to pursue their claims. ${ }^{57}$ As Gideon Parchomovsky and Alex Stein have observed, "When an entitlement holder does not have the financial wherewithal to vindicate the entitlement in court, the entitlement will fail to protect her regardless of its classification as a right in personam or a right in rem. ${ }^{, 5}$ Simply, an individual will not sue to vindicate her right if she cannot afford to do so. As a consequence, the right will fail to accomplish its purpose. $^{59}$ Richard Posner, discussing contingent fees as a means of access to legal remedies for illiquid individual plaintiffs, ${ }^{60}$ has noted, "The likelier a suit is to be brought if there is a violation of law that causes injury, the greater is the deterrent effect of whatever legal principle the suit would enforce, and hence the less likely are potential defendants to engage in the forbidden conduct." ${ }^{\prime 61}$ Thus, increased litigation can aid in the enforcement of legal rights and entitlements both by increasing the opportunities for rights holders to vindicate their rights and by deterring potential defendants from encroaching on those rights in the first place. ${ }^{62}$

While incentivizing, or disincentivizing, litigants to pursue litigation

57. See generally POSNER, supra note $49, \S 21.11$ (discussing access to legal remedies through contingent fees, class actions, and indemnity of legal fees).

58. Parchomovsky \& Stein, supra note 48, at 1338.

59. It is almost axiomatic, but from a policy perspective it is desirable to enforce rights. Per Parchomovsky and Stein,

Loss of entitlements on account of high enforcement costs should alarm policymakers for several reasons. First, and most obviously, it harms the entitlement holder. Rights theorists may disagree whether the harm is to her personhood, autonomy, or wellbeing, but none will contest the fact that she suffered some serious harm. Second, entitlement erosion undermines the goals of society at large since it upsets the balance of powers and freedoms within society. After all, entitlements are granted for a reason and their systematic non-enforcement therefore impairs policymaking. Third, the possibility of 'entitlements' erosion creates a perverse incentive for third parties to deliberately intrude on 'others' entitlements. Correspondingly, it induces inefficient changes in the behavior of entitlement holders who foresee the possibility that they will not be able to enforce their legal rights and privileges.

Id. at 1333 .

60. Providing access to legal remedies through litigation is one purpose of contingent fee contracts, class actions suits, and attorney fee shifting rules. See PoSNER, supra note 49, § 21.11. In a sense, all three are procedures for allocation of legal expenses.

61. Id. at 615.

62. A system that allocates all of the costs of litigation to a right holder's opposing party if the right holder succeeds in vindicating her right would reduce the costs of enforcement and, logically, incentivize the right holder to bring suit. Such a system would thereby increase the level of litigation. The inverse is also true. A system in which the parties' legal costs were allocated to the right holder if she failed in vindicating her right would decrease the level of litigation. See Shavell, supra note 51, at 55 (evaluating the economic effects of different fee shifting systems to determine which increase and decrease the number of suits brought and number of settlements reached in lieu of trial). 
appears to be a prevalent rationale for cost allocation schemes, it is not the only one. As writers in the area have noted, there are myriad reasons policymakers and judges might choose a particular cost allocation system, and the reasons are not always clear. ${ }^{63}$ Thomas D. Rowe, Jr., for example, has identified six common rationales underpinning systems of allocating attorney fees. ${ }^{64}$ These rationales include indemnifying the winner based on simple fairness, making the winner truly whole, deterring misconduct, rewarding "private attorneys general," and affecting the relative strengths of the parties. ${ }^{65}$ We will explain each of Rowe's rationales in more detail below as they relate to our discussion of the major schemes of cost allocation.

\section{B. Schemes of Litigation Cost Allocation}

Only a few common cost allocation schemes exist. Broadly, these fall into two categories: non-fee-shifting, known as the "American rule," and fee-shifting. The fee-shifting category can be subdivided into the indemnity system and one-way shifting systems. ${ }^{66}$ In the following subsections, we will briefly describe each common system of cost allocation, paying particular attention to the rationales underlying each system and each system's effect on litigation levels.

\section{The American, Non-Fee-Shifting System}

In American jurisdictions, litigants pay their own legal costs, win or lose, absent a contrary statute or judge-made exception. ${ }^{67}$ This method of

63. See, e.g., Thomas D. Rowe, Jr., The Legal Theory of Attorney Fee Shifting: A Critical Overview, 1982 DUKE L.J. 651, 651-52, 658 (1982) ("There exist, indeed, several different sorts of reasons why a legal system might choose a policy of requiring losing litigants to pay winners' legal fees in some or all cases."); Dan B. Dobbs, Awarding Attorney Fees Against Adversaries: Introducing the Problem, 1986 DUKE L.J. 435, 445 (1986) ("The justification for imposing strict fee liability upon a litigant merely because he loses is less clear, however."); John Leubsdorf, Toward a History of the American Rule on Attorney Fee Recovery, 47 LAW \& CONTEMP. PROBS. 9, 9 (1984) ("As far back as one can trace, courts in this country have allowed winning litigants to recovery their litigation costs from losers only to the extent provided by the legislature. But closer examination reveals that the justification of this rule and its significance in the economy of litigation have varied over the years.").

64. Rowe, Jr., supra note 63, at 651-53.

65. Id. at 653 .

66. See Shavell, supra note 51, at 55 (identifying the non-shifting "American system," the indemnity, or "British system," one-way shifting in favor of defendant, and one-way shifting in favor of plaintiff as common methods of cost allocation).

67. See Black's LAW Dictionary 92 (8th ed. 2004) (defining "American rule"); Parchomovsky \& Stein, supra note 48 , at 1363 . The so-called American rule supposedly emerged 
allocation of legal expenses has been termed the "American rule." ${ }^{68}$ The American rule is anomalous. It is unique in the common law world, ${ }^{69}$ and differs from the predominant system in Continental Europe. ${ }^{70}$ The exact origins of the American rule are somewhat mysterious. ${ }^{71}$ Early colonial legislation provided for fee recovery in conformity with the English system of indemnity. ${ }^{72}$ But as attorney fees were deregulated in the decades following the American Revolution, the pay-your-own-way system came to dominate. ${ }^{73}$ Since taking hold around the nineteenth century, the American rule has withstood numerous significant statutory and common law exceptions. $^{74}$

The American rule is considered to generally encourage litigation as compared to systems that indemnify the winner's fees. ${ }^{75}$ The American rule has been criticized for promoting "wasteful litigation expenditures." instance of nuisance suits is, theoretically at least, likely higher under the American system. ${ }^{77}$ The other side of the coin, however, is that the

from the early United States Supreme Court opinion of Arcambel v. Wiseman, 3 U.S. (3 Dall.) 306 (1796). Dobbs, supra note 63, at 435 n.2. The Arcambel Court held simply that $\$ 1,600$ in counsel's fees, which the lower court had permitted the winner to recover as part of his damages, was not properly recoverable. Arcambel, 3 U.S. (3 Dall.) at 306. The Court stated, without explanation, "The general practice of the United States is in opposition to it; and even if that practice were not strictly correct in principle, it is entitled to the respect of the court, till it is changed, or modified, by statute." Id. Despite this pronouncement from the early Court, the law in the United States on attorney fee recovery was not clear. Leubsdorf, supra note 63, at 15. The "rule" from Arcambel would have had little if any authority, "since at that time federal courts did not play a creative role but followed state costs practice." Id. (citing Costs in Civil Cases, 30 F. Cas. 1058 (S.D.N.Y. 1852)). Courts have cited, and continue to cite, Arcambel as recognizing the general rule that fees are not recoverable in the American system. Id.

It is also noteworthy that, even under the American rule, the minor items of cost, including court fees, copying costs, and witness fees, are recoverable. It is the big-ticket item, attorney fees, that is not recoverable under the American rule. POSNER, supra note 49, $\S 21.12$, at 621 n.2.

68. Parchomovsky \& Stein, supra note 48, at 1362-63.

69. Williams, supra note 53 , at 859.

70. See POSNER, supra note $49, \S 21.11$, at 617 .

71. See supra note 23 and accompanying text.

72. Leubsdorf, supra note 63, at 10-13.

73. Id. at $13-17$.

74. See id. at 28.

75. Cf. Williams, supra note 53, at 860 ("Although designed to provide an indemnity, the practice of awarding fees to the successful party also serves to discourage litigation, certainly the trial of an action.").

76. Note, Bradley L. Smith, Three Attorney Fee-Shifting Rules and Contingency Fees: Their Impact on Settlement Incentives, 90 MicH. L. REV. 2154, 2154-55 (1992) (citing criticisms of the American rule).

77. See Shavell, supra note 51, at 59-60. One definition of a nuisance suit is a suit with a low probability of success in which the plaintiff's litigation costs will exceed the amount of the expected judgment. David Rosenberg \& Steven Shavell, A Model in Which Suits Are Brought for Their Nuisance Values, 5 INT'L REV. L. \& ECON. 3, 3 (1985). Importantly, nuisance suits are not 
American system provides wider access to justice. ${ }^{78}$ Whether the American rule's effect on the level of litigation is more virtue or vice is a normative question. As Thomas Rowe has observed, "American attitudes ... tend to regard litigation as everyone's right and to emphasize the importance of not excessively hindering access to justice." 79

The American rule also tends to promote out-of-court settlements as "making the losing party pay the winning party's attorney's fees would reduce, not increase, the settlement rate. ${ }^{\circ 0}$ Under the American rule, a party has an incentive to settle before trial to avoid the legal expenses of taking the case to trial regardless of the party's relative confidence in winning at trial. Under a rule that indemnifies the winning party's fees, settlement makes less sense for a party who is confident in her chances of winning. ${ }^{81}$ Thus, even though more claims are brought under the American system of expense allocation, it does not necessarily follow that there are more trials. ${ }^{82}$

\section{Systems of Attorney Fee Shifting}

The second broad category of cost allocation after the American rule is attorney fee shifting. Under fee shifting systems, the legal expenditures of the parties are allocated based on the results of the litigation rather than strictly on which party incurred the expense. Fee shifting schemes commonly fall into one of two subcategories, indemnity and one-way shifting. Each subcategory is described in turn in the subsections that follow.

a. Indemnity, or the English Rule

While American courts allocate legal expenditures based solely on

necessarily frivolous. According to Posner,

A suit is frivolous if it has no basis in law, implying a very low probability of the plaintiff's winning if the suit is litigated. A nuisance suit might be a meritorious suit in which the potential damages were so slight that the net expected value of the suit (that is, net of the plaintiff's litigation costs), if it were litigated, would be negative.

POSNER, supra note 49, § 21.11, at 620.

78. Parchomovsky \& Stein, supra note 48 , at 1363.

79. Rowe, Jr., supra note 63, at 658 (citing Corboy, Contingency Fees: The Individual's Key to the Courthouse Door, 2:4 Litigation 27 (Summer 1976)).

80. Richard A. Posner, Comment on Donohue, 22 LAW \& SoC'Y REv. 927, 927 (1988); see Shavell, supra note 51, at 63.

81. See Shavell, supra note 51, at 65-66.

82. Id. at $65-66$ n.39. 
which party incurs them, courts in other common law jurisdictions and in civil law jurisdictions allocate expenditures based on which party ultimately prevails in the litigation. ${ }^{83}$ This system is known as "indemnity," or commonly the "English rule." Under the indemnity rule, the loser of litigation pays both her own legal expenses and those of the prevailing party. The rule shifts the winner's legal fees to the loser to pay, regardless of whether the winning party was plaintiff or defendant. Consequently, the rule is also sometimes called a "two-way fee shifting" rule. ${ }^{84}$

In Thomas Rowe's theoretical analysis of attorney fee shifting schemes, he points to "justice for the winner" as the most appealing justification for the indemnity rule. ${ }^{85}$ The prevailing party in litigation, this argument goes, "should not suffer financially for having to prove the justice of his position." ${ }^{\text {"T6 }}$ This equitable rationale does not itself justify forcing the loser to indemnify the winner, according to Rowe. It is possible, even probable, for a defeated party "to have been justified and reasonable in pressing a strong but ultimately unsuccessful claim or defense. ${ }^{, 87}$ It does not serve equity to penalize a losing party for advancing reasonable arguments. In this way, indemnity may not be fairer or more equitable than the American rule.

Because requiring the loser to pay the other side's expenses is at least somewhat punitive, the indemnity rule finds further justification in theories of punishment and deterrence. To the extent that losing parties lose because of the wrongfulness of their underlying conduct, indemnity punishes such wrongful conduct and may deter the losing party, and perhaps third parties, from similar wrongful conduct in the future. As explained below, deterrence and punishment are common rationales for one-way fee shifting schemes, as well. ${ }^{88}$

A more compelling justification for the indemnity rule is compensation. The basis for the law of remedies is to make the plaintiff whole. Yet, under

\footnotetext{
83. Williams, supra note 53, at 859; see POSNER, supra note 49, § 21.11, at 617.

84. Rowe, Jr., supra note 63 , at 653 \& n.8.

85. Id. at 653-54.

86. Id. at 654 .

87. Id. at 655. Rowe notes, however, that in a legal system in which substantive law and litigation outcomes is generally predictable, it may indeed serve equity to penalize a losing party for losing. Id. Such a loser should have known better than to continue the litigation and cause the opposing party to incur increasing expenses. Id. While the British legal system, for instance, tends to produce predictable outcomes (in part because of its non-political bench and infrequent use of juries), the American legal system does not. Id. at 655-56 (citing POSNER, supra note 49, § 21.11, at 619; Letter from Benjamin N. Cardozo to H.H. Nordlinger, in G. Hellman, Benjamin N. CARdozo: AMERICAN Judge 150 (1940)). Consequently, the indemnity rule may be fairer in application in the British system than in the American system.
}

88. See infra Part III.2.b. 
the American rule, even a successful plaintiff is not truly made whole because she cannot recover all of her legal costs. Again, per Rowe, "Undeniably, the American rule's effect of reducing a successful plaintiff's recovery by the amount of his lawyer's fee conflicts with the make-whole idea underlying much of the law of remedies." 89 Indemnity, on the other hand, ensures that if a plaintiff successfully vindicates a right or entitlement she recovers her costs of doing so, which she would not have incurred but for the illegal conduct of the defendant.

Finally, indemnity is often credited with discouraging litigation. ${ }^{90}$ Indeed, advocates of indemnity consider it an answer to the "caseload crisis." ${ }^{\prime 11}$ Steven Shavell's economic analysis of the indemnity rule indicates the system theoretically holds down the number of nuisance suits. ${ }^{92}$ Empirically, however, it appears that indemnity might actually increase the litigation rate. $^{93}$ Either way, the indemnity rule generally makes litigation more expensive because it encourages litigants to spend heavily in expectation that the costs will ultimately fall to the other side. ${ }^{94}$ Moreover, in much the same fashion, the indemnity rule incentivizes more trials than the American rule. ${ }^{95}$

\section{b. One-Way Fee Shifting Schemes}

The second common type of fee shifting scheme is a one-way shift. In contrast to the indemnity rule, or "two-way" shift, a one-way shift makes fees recoverable by only one type of party in litigation, plaintiff or defendant. While a one-way fee shift can favor either the plaintiff or the defendant, one-way shifts that favor defendants are rare. The typical oneway shift rewards fees to the prevailing plaintiff only. ${ }^{96}$

One-way fee shifting schemes are uniquely American. Where they exist, they are exceptions to the general American rule. Except for

\footnotetext{
89. Rowe, Jr., supra note 63 , at 657.

90. See, e.g., Williams, supra note 53 , at 860 .

91. POSNER, supra note $49, \S 21.11$, at 618 .

92. Shavell, supra note 51, at 59-60.

93. See generally Edward A. Snyder \& James W. Hughes, The English Rule for Allocating Legal Costs: Evidence Confronts Theory, 6 J.L. ECON. \& ORG. 345 (1990) (concluding that plaintiffs dropped more medical malpractice claims under an English rule indemnity rule than under the American rule).

94. PosNer, supra note $49, \S 21.11$, at 620 ; see Snyder \& Hughes, supra note 93, at 346 (noting empirical evidence suggesting litigations costs are higher under the indemnity rule).

95. Shavell, supra note 51, at 59-60.

96. See Dobbs, supra note 63, at 435-36.
} 
commercial contracts that included private fee shifts, the American rule prohibiting attorney fee shifting was practically monolithic until the $1870 \mathrm{~s}^{97}$ Starting around this time, federal legislation began to integrate one-way, plaintiff-friendly fee shifts. ${ }^{98}$ The first legislative fee shifts came in the Voting Rights Act of 1870, the Interstate Commerce Act of 1887, and the Sherman Act of $1890 .^{99}$ Numerous subsequent state statutes also allowed fee recovery. ${ }^{100}$ According to John Leubsdorf, "Legislatures of this period were beginning to look at realistic attorney fee awards less as bounties for greedy lawyers and more as aids to needy plaintiffs or sanctions against corporate defendants." type of litigation. In the mid- to late-nineteenth century in America, the typical lawsuit "ceased to be a businessman's action to recover a debt and became a tort suit against a corporation."102 A second major round of legislative fee shifts came almost a century later in 1960s and 1970s. Congress included fee shifting provisions, nearly all plaintiff friendly, in virtually all civil rights and environmental statutes during these decades. ${ }^{103}$

Courts of this era also began actively expanding exceptions to the American rule by, among other things, broadly interpreting fee shifting provisions and developing the "private attorney general doctrine."104 The United States Supreme Court made the private attorney general doctrine federal law in Newman v. Piggie Park Enterprises, Inc. ${ }^{105}$ In Newman, the Court interpreted the fee shift provision in Title II of the Civil Right Act of 1964. Title II provides that "the prevailing party" is entitled to "a reasonable attorney's fee in the court's discretion." "106 The Court took up the question of whether Title II allowed recovery of attorney fees only to the extent the defendants advanced bad faith positions. ${ }^{107}$ The Newman Court succinctly stated the purpose of the fee shift in Title II as follows:

\footnotetext{
97. Leubsdorf, supra note 63 , at 25.

98. Id.

99. Id.

100. Id.

101. Id.

102. Id. at 25-26.

103. Id. at 30 .

104. Id.; see, e.g., Newman v. Piggie Park Enterprises, Inc., 390 U.S. 400, 401-02 (1968) (interpreting the fee shift in Title II of the Civil Rights Act of 1964 to award fees not just for bad faith claims by defendants but also to compensate plaintiffs for acting as a "private attorney general").

105. Newman, 390 U.S. at 401-02.

106. 42 U.S.C. $\S 2000 a-3(b)$.

107. Newman, 390 U.S. at 401.
} 
When the Civil Rights Act of 1964 was passed, it was evident that enforcement would prove difficult and that the Nation would have to rely in part upon private litigation as a means of securing broad compliance with the law. A Title II suit is thus private in form only. When a plaintiff brings an action under that Title, he cannot recover damages. If he obtains an injunction, he does so not for himself alone but also as a 'private attorney general,' vindicating a policy that Congress considered of the highest priority. If successful plaintiffs were routinely forced to bear their own 'attorneys' fees, few aggrieved parties would be in a position to advance the public interest by invoking the injunctive powers of the federal courts. Congress therefore enacted the provision for counsel fees - not simply to penalize litigants who deliberately advance arguments they know to be untenable but, more broadly, to encourage individuals injured by racial discrimination to seek judicial relief under Title II. ${ }^{108}$

Significantly, Newman interpreted fee shifting provisions in federal civil rights legislation to be more than merely a penalty for defendants. Rather, fee shifts are intended to reward plaintiffs who bring claims to enforce federal laws and policies, much like the attorney general does. ${ }^{109}$ The private attorney general doctrine has enjoyed wide application since Newman, including in certain contexts in Kansas law. ${ }^{110}$

The history of one-way fee shifting clearly indicates three rationales underpinning these schemes: punishing corporate wrongdoers, affecting the relative strengths of the parties, and incentivizing plaintiffs to vindicate statutory rights. Given their history and the rationales used to justify them, it is no wonder that one-way fee shifts predominately favor plaintiffs over defendants. This is the case in in most federal civil rights cases. Under 42 U.S.C. $\S 1988(b)$, attorney fees are recoverable by the prevailing party in actions under $\S \S 1981,1983$, and Title VI of the Civil Rights Act of 1964, and other federal statutes. While the language of $\S 1988$ allows recovery by either defendants or plaintiffs, the Supreme Court has interpreted the provision to allow defendants to recover fees only if the plaintiff's claim was "frivolous, unreasonable, or groundless." I11 In other words, the fee shift in $\S 1988$ is plaintiff friendly. The Supreme Court has three reasons for

\footnotetext{
108. Id. at 401-02 (emphasis added)
}

109. Id.

110. See Alexander v. Certified Master Builders Corp., 1 P.3d 899, 906-07 (Kan. 2000) (applying the doctrine to the remedial provisions of the Kansas Consumer Protection Act); Williams Foods, Inc. v. Eastman Chem. Co., No. 99C16680, 2001 WL 1298887, at *6 (D. Kan. Aug. 8, 2001) (applying the doctrine to the Kansas civil antitrust statutes).

111. Christianburg Garment Co. v. EEOC, 434 U.S. 412, 422 (1978); see also Michael T. Jilka, Attorneys Fees in Civil Rights Cases, J. KAN. B.A., Nov./Dec. 2005, at 42, 42; Dobbs, supra note 63, at $442-50$. 
distinguishing between plaintiffs and defendants: (1) the need to facilitate the enforcement of civil rights laws through the private attorney general doctrine; (2) it avoids creating a disincentive for plaintiffs by allowing successful defendants to collect attorney fees; and (3) when a court awards fees for a plaintiff, it "is awarding them against a violator of federal law.",

Consistent with the purposes of one-way fee shifts, plaintiff-friendly shifts tend to increase the frequency of lawsuits and trials. ${ }^{113}$ The rare defendant-friendly shifts, logically, tend to decrease the frequency of suits. ${ }^{114}$ Steven Shavell's conclusion, consequently, would likely be to institute a one-way plaintiff-friendly scheme in areas of the law in which higher volumes of litigation are desirable. This is precisely what the Supreme Court has done with the private attorney general doctrine in the civil rights context.

\section{ATtORnEY FeE SHIFTS IN THE WAGE PAYMENT AND COLLECTION STATUTES OF OTHER JURISDICTIONS}

While not every state has adopted a full-blown wage payment and collection act like Kansas's KWPA, almost all jurisdictions have codified some sort of statutory remedial scheme for employees to recover unpaid wages from employers. Among other things, this fact illustrates the nearuniversality of the public policy supporting timely and complete payment of wages earned. Furthermore, most of these statutory remedial schemes involve an attorney fee shift, and most of these shifts exclusively benefit plaintiff-employees. One can infer at least two broad conclusions from these facts: a majority of jurisdictions attempt to incentivize employees to bring private causes of action to recover unpaid wages, and Kansas is in the minority.

Appendix A contains the results of the authors' fifty-one jurisdiction survey (including all fifty states and the District of Columbia) of attorney fee shifts in wage payment and collection and similar statutes. The results of this survey are telling. A large majority of jurisdictions have provided for attorney fees as part of the potential recovery in wage claims. In a nutshell, of the forty-eight jurisdictions in the United States that have adopted some sort of wage payment and collection statute, ${ }^{115}$ thirty-nine (all but seven)

\footnotetext{
112. Jilka, supra note 111, at 42 (citing Christianburg Garment Co., 434 U.S. at 422).

113. Shavell, supra note 51, at $61,67$.

114. Id. at 61 .

115. Alabama, Mississippi, and Ohio provide no statutory method of recovery of due and owing wages.
} 
have included an attorney fee shift in the respective statute. Kansas, along with Georgia, Missouri, New Jersey, North Dakota, South Dakota, and Virginia are in the small minority of states whose wage payment statutes include no fee shift.

The most typical type of fee shift in wage payment and collection statutes is a one-way shift that favors only the plaintiff. These one-way shifts tend to fall into one of a few subcategories: (a) statutes that require a fee award for the prevailing plaintiff only; (b) statutes that give the court discretion to award fees for the plaintiff only; (c) statutes that reward defendants fees if the plaintiff's claims are deemed frivolous or brought in bad faith; and (d) statutes that reward plaintiffs fees except when the defendant's violation of the law was the result of a bona fide dispute. Although much less common, some jurisdictions' statutes provide for indemnity of the prevailing party's attorney fees, regardless of which party prevails. Only Arizona and Florida have codified this English-style indemnity rule. Washington and Colorado each have adopted a rule that operates like an offer of judgment in that fees are recoverable by the plaintiff only if the plaintiff's ultimate recovery is greater than the amount admitted by the employer to be owing. ${ }^{116}$ Colorado permits the employer to recover fees when the plaintiff's ultimate recovery is less than the amount admitted by the employer. ${ }^{117}$ Montana has adopted yet another variant of indemnity in which the plaintiff must be awarded fees if he or she prevails and the defendant may be awarded fees if he or she or it prevails. ${ }^{118}$

Below is a table summarizing the types of fee shifts found in the wage payment and collection statutes analyzed in the fifty-one jurisdiction survey. This table paints with a broad brush. Many of the fee shifts analyzed are unique and incapable of being categorized perfectly in this general manner. It suffices for our purposes here, however, to describe the rough contours of the types of fee shifts employed by other jurisdictions in their wage payment statutes.

116. Colo. Rev. Stat. AnN. § 8-4-110(1); Wash. Rev. Code $\$ 49.48 .030$.

117. Colo. Rev. Stat. AnN. § 8-4-110(1).

118. MonT. CODE ANN. § 39-3-214. It should be noted that the Montana statute requires courts to award attorney fees to prevailing plaintiffs except when the action is brought by the commission of labor. 


\begin{tabular}{|l|l|l|l|l|l|l|}
\hline & No Shift & Indemnity & $\begin{array}{l}\text { One-Way, } \\
\text { Plaintiff- } \\
\text { Friendly } \\
\text { (Discretionary) }\end{array}$ & $\begin{array}{l}\text { One-Way, } \\
\text { Plaintiff- } \\
\text { Friendly } \\
\text { (Mandatory) }\end{array}$ & $\begin{array}{l}\text { One-Way, } \\
\text { Plaintiff- } \\
\text { Friendly } \\
\text { (except if } \\
\text { claim is } \\
\text { frivolous) }\end{array}$ & $\begin{array}{l}\text { One-Way, } \\
\text { Plaintiff- } \\
\text { Friendly } \\
\text { (only if no } \\
\text { bona fide } \\
\text { dispute) }\end{array}$ \\
\hline $\begin{array}{l}\text { Juris- } \\
\text { dictions }\end{array}$ & $10^{119}$ & 6 & 17 & 12 & 3 & 3 \\
\hline $\begin{array}{l}\text { Percent } \\
\text { of } \\
\text { Total }\end{array}$ & $19 \%$ & $12 \%$ & $33 \%$ & $24 \%$ & $6 \%$ & $6 \%$ \\
\hline
\end{tabular}

It is clear from these results that a consensus exists among states that employees ought to be able to recover their attorney fees along with unpaid wages. It is less clear what rationales the majority states have adopted to justify the fee shift. Likely rationales include the desire to affect the relative strength of the parties, to incentivize private wage payment litigation to enforce the law and support public policy, and to punish employers that wrongfully withhold earned wages. These majority states have effectively authorized individual aggrieved employees to act as private attorneys general in enforcing the wage payment and collection laws.

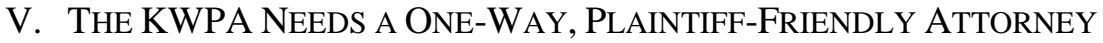 FEE SHIFT TO INCENTIVIZE PRIVATE ENFORCEMENT OF THE LAW}

If it is true, as the Kansas Legislature and Kansas courts have stated, ${ }^{121}$ that the KWPA is necessary to enforce the "strong and longtime" public policy of the state to protect workers' wages, the Act should be amended to include an award of attorney fees for prevailing plaintiffs. At bottom, the KWPA suffers a peculiar enforcement problem because the class of people it is intended to protect, unpaid wage workers, is uniquely incapable of pursuing a private cause of action in court. By virtue of being a member of the protected class, a person is cash-strapped because she has not been paid her wages. The legislature entrusted the KDOL with enforcement of the law, and even granted it a fee shift to make enforcement possible. It appears

119. Includes jurisdictions with no wage payment statute.

120. Based on total jurisdictions surveyed, i.e., fifty-one.

121. See Coma Corp. v. Kan. Dep't of Labor, 154 P.3d 1080, 1092 (Kan. 2007). 
that the task of enforcing the KWPA is more than the KDOL can manage. As a result, the "strong and longtime" public policy protecting wages and wage earners is hollow.

There are three reasons the KWPA must be amended to include an attorney fee shift favoring prevailing plaintiffs. First, an attorney fee shift is justified by fundamental fairness. Second, an attorney fee shift would make it possible for individual employees with small claims - the majority of people aggrieved under the KWPA - to vindicate their rights and enforce the entitlements granted by the Act. And third, a fee shift would permit individual employees to enforce the KWPA as private attorneys general and thereby improve enforcement and ease the burden on state government.

Before we discuss these reasons in detail, it will be helpful to clarify the type of fee shifting provision we are proposing. Kansas should join the majority of states and amend its wage payment and collection act to award attorney fees to prevailing plaintiffs. The original bill introduced in the Kansas House of Representatives in 1973 contained a one-way, plaintifffriendly fee shift. The shift was included in what is today section 44-324. Subsection (c), the fee shift, read as follows:

(c) Any judgment for the plaintiff in a proceeding pursuant to this act shall include all costs reasonably incurred in connection with the proceeding, including attorneys' fees. ${ }^{122}$

A one-way, plaintiff-friendly fee shift, like the one originally proposed in House Bill 1429, is necessary and appropriate to achieve the goals of fairness to employees, enforcement of the rights protected by the KWPA, and easing the burden of enforcement on the state.

Recognizing that there is no reason to incentivize employees to bring meritless claims or claims intended merely to harass or abuse their employers, we recommend modifying the original one-way fee shift to allow a prevailing defendant to recover fees under these circumstances. We propose the following language to accompany the above fee shifting provision:

If the Court determines that plaintiff knowingly brought and maintained a groundless action pursuant to this act, then the prevailing defendant may be entitled to recover from plaintiff all costs reasonably incurred in connection with the proceeding, including attorneys' fees.

122. H.B. 1429,1973 Leg., 68 th Sess., at 8 (Kan. 1973). 
The following subsections explain the reasons for and benefits of such an attorney fee shift.

\section{A. Fundamental Fairness Demands that the KWPA Include an Attorney Fee Shift}

It is unfair to require a wage-earning employee whose employer has wrongfully withheld wages to foot the bill for an attorney on an hourly basis to recover from her employer. This is, however, the only choice most potential wage payment plaintiffs have. Those who cannot afford to pay a private attorney hourly - which is likely because they have not been paidsimply receive no redress. In other words, prospective wage payment plaintiffs are practically barred from recovering their earned wages precisely because they were never paid their earned wages. This is unfair. Moreover, even those employees who manage to find a private lawyer to take their case and go on to prevail are never made whole. An employee who recovers $100 \%$ of her owed wages plus a $100 \%$ penalty still likely owes her lawyer fees. The penalty, though substantial, may not (and usually does not) cover the attorney fees. A successful plaintiff, therefore, is rarely made whole, which is fundamentally unfair.

Further, an attorney fee shift is essential to leveling the relative strengths of the parties in wage payment litigation. Employers that violate the KWPA by failing to pay earned wages to an employee enjoy important structural advantages in wage payment litigation. First, employers generally possess the financial wherewithal to retain legal counsel on an hourly basis. In fact, employer-violators possess the funds withheld from the employee-victim, which could be applied to the former's litigation costs. Second, employers often possess most or all of the relevant evidence in a case. Discovery, therefore, is often more burdensome and time consuming for the employee than for her opponent.

These advantages do not relate in any way to the merits of the parties' positions. Yet, as a consequence of these advantages, litigation is relatively less expensive for employers than for employees. A statutory attorney fee shift would even the playing field by affecting the relative strengths of the parties. If an employer were liable for its fees as well as the employee's fees, the structural cost advantages previously available to the employer would disappear and so, too, would the unfairness inherent in the current system. 


\section{B. A Fee Shift Is Necessary to Enforce the Rights Codified in the KWPA}

Rights are meaningful only to the extent they can be enforced. Unenforceable rights are really no rights at all. This is the argument of Parchomovsky and Stein, cited supra, ${ }^{123}$ and it is true as it relates to the rights supposedly protected by the KWPA. Under the current system in which there is no attorney fee shift for private claims under the Act, most claims are too small to justify the legal costs necessary to pursue them, and, as a consequence, lawyers will not take the claims on a contingency. Thus, unless an aggrieved employee is able to bear the costs of hourly bills for an attorney, she is unable to bring a claim to enforce her rights under the KWPA. ${ }^{124}$ In this common scenario, the effect of the KWPA is nil; the rights to wages it purports to protect are accordingly nonexistent. The Act is not accomplishing its purpose.

When aggrieved employees are unable to vindicate their rights to wages through private causes of action, there is no deterrent to employers from wrongfully withholding wages. Rational employers will safely withhold an amount of wages that, while significant to the employee, is insufficient to justify the costs of prosecuting a wage payment claim. In the status quo, there is no check on relatively minor violations of the KWPA.

The solution to problems like this one, according to Richard Posner, is more litigation against the violators of the law. ${ }^{125}$ Posner says that the more likely a suit is to be brought to enforce a right, the greater the deterrent effect of the law. ${ }^{126}$ Hence, employers who might otherwise withhold an employee's wages are likelier to be deterred from doing so if a related lawsuit is likely. If one assumes, as do the authors and Kansas courts and lawmakers, that the rights protected by the KWPA are important and should be enforced, then increased wage payment litigation must be desirable. ${ }^{127}$ Thus, legal costs should be allocated to incentivize employees to bring wage payment litigation. ${ }^{128}$

The most effective way to allocate legal costs to incentivize potential plaintiffs to bring claims is to award prevailing plaintiffs their attorney fees

123. See supra notes 58-59 and accompanying text.

124. This assumes, of course, that the hypothetical employee is unable to seek redress through the KDOL. As discussed supra, the KDOL pursues very few wage complaints and most often refers the complainants to private counsel.

125. See supra note 61 and accompanying text.

126. Id.

127. See generally Shavell, supra note 51.

128. Id. 
using a one-way, plaintiff-friendly fee shift. ${ }^{129}$ This is precisely what most other states have done to enforce workers' rights to wages. ${ }^{130}$ Nearly $70 \%$ of American jurisdictions have adopted one-way, plaintiff-friendly fee awards for this purpose. ${ }^{131}$ Kansas should join the majority and enable employees to vindicate their rights through private causes of action and simultaneously deter employers from withholding wages in the first place.

Consider the ground-level example where an employer tells her employee he will receive a bonus of $\$ 1,000$ by hitting quarterly targets. After the employee hits his production targets, he is lulled along for weeks, and then months, without being paid the bonus. Then he gets another job after the employer refuses to honor the deal. Under present law, the wage claim is worth $\$ 2,000$ at most. Yet the documentary evidence to build the claim - including evidence of similar production bonuses in the past, internal emails, and contact information of former employees - is in the employer's possession. No reasonable lawyer will take this case without a fee shift. And the KDOL will not undertake discovery to prove that an oral promise was in fact made. This and similar examples from actual practice demonstrate that KWPA rights are presently not enforced.

\section{A Fee Shift in the KWPA Would Deputize Employees as Private Attorneys General and Ease the Burden of Enforcement on the State Government}

An attorney fee shift that benefits the prevailing plaintiff would permit private parties to sue to enforce the KWPA in much greater numbers than in the status quo. In other words, an attorney fee shift would deputize aggrieved employees as private attorneys general. The KDOL accordingly would bear less of the enforcement burden. From the perspective of aggrieved wage earners, it should not matter how or by whom the KWPA is enforced, so long as it is. As we argue in this section, however, there are reasons to prefer private as opposed to governmental enforcement of the KWPA. First, private enforcement would strengthen the law without burdening the state's budget. And second, private enforcement is consistent with the concept of a smaller, less powerful state government.

The first reason to prefer private enforcement of the KWPA, as opposed to enforcement by the KDOL or other agency or arm of the state, is that

\footnotetext{
129. See supra Part II.B.2.b.

130. See supra Part III \& Appendix A.

131. See supra Part III \& Appendix A.
} 
private enforcement is virtually free of cost to the state. This advantage is meaningful, particularly in a time, such as the present, when the state's budget is very tight. The private attorney general doctrine, which federal courts have used as a rationale for awarding prevailing plaintiffs with their attorney fees, ${ }^{132}$ was conceived for the reason that the government's ability to enforce laws is limited. The primary limits are time and financial expense.

These limitations, especially financial expense, are a concern for the State of Kansas in this era of budget restrictions. The first half of fiscal year 2014 has seen steep revenue declines for the State of Kansas. ${ }^{133}$ Expenses, on the other hand, have proven difficult to cut, especially for education and courts. ${ }^{134}$ The Kansas Legislative Research Department estimated in January 2014, that, if nothing changed, the state would suffer a budget shortfall of $\$ 900$ million by fiscal year $2019 .{ }^{135}$ This is not an appropriate fiscal climate in which to increase state spending on wage payment enforcement. Assuming, as we do, that the KDOL's modest efforts at KWPA enforcement are partly a function of the limits of time and money, there is no reason for optimism as long as the state's budget crunch persists.

The solution is to privatize enforcement of the KWPA. This can be done by simply amending the Act to include an attorney fee shift favoring prevailing plaintiffs, i.e., vindicated wage-earning employees. Such a fee shift would incentivize private lawyers to take small wage collection cases and thereby empower individual aggrieved employees themselves to enforce the mandates (and public policy) of the KWPA, without need for public spending. ${ }^{136}$

Furthermore, private enforcement of laws is consistent with the

132. See supra notes $104-10$ and accompanying text.

133. Brad Cooper, Kansas Tax Revenues Fall While Other States See Rise, KAN. CITY STAR (May 10, 2014), http://www.kansascity.com/2014/05/10/5014648/kansas-tax-revenues-fallwhile.html.

134. Peter Coy, Kansas Tries to Shrink Its Way to Prosperity, BloombergBusinessweek (Apr. 17, 2014), http://www.businessweek.com/articles/2014-04-17/kansas-governor-brownbackslab-for-steep-tax-and-budget-cuts; see also Kansas Court Furloughs Possible Under New Budget, HuTCHINSON NEws (Apr. 14, 2014, 10:56 AM), http://www.hutchnews.com/news/local_state_news /article_476fe81a-c3ed-11e3-b577-0019bb2963f4.html.

135. Coy, supra note 134.

136. The authors recognize that courts are publicly funded and that, as a consequence, enforcement of the KWPA through private litigation is not a perfectly "private" enforcement mechanism. The incremental cost to the public of increased numbers of private wage payment lawsuits would be substantially less expensive than increased enforcement through the KDOL, however. 
libertarian ideal of a smaller, less powerful government. ${ }^{137}$ Consequently, enforcement of the KWPA by private attorneys general, via a one-way, plaintiff-friendly attorney fee shift, is consistent with libertarian small-state principles.

\section{CONCLUSION}

In light of the purpose and "strong and longtime" public policy underpinning the KWPA, the law needs greater private enforcement and therefore an attorney fee provision. Without an attorney fee shift, aggrieved employees are unfairly denied an opportunity to vindicate their rights under the KWPA. They are effectively shut out, as though the Act did not exist. As a further consequence, the rights codified and supposedly protected in the KWPA are hollow. A one-way, plaintiff-friendly attorney fee shift would deputize individual employees as private attorneys general authorized not only to vindicate their individual rights, but also to enforce the law and public policy of the State of Kansas. And they would do so without further expense for the state itself; their efforts would be paid for by the violators of Kansas law.

137. See generally Murray N. Rothbard, Law, Property Rights, and Air Pollution, CAto J., Spring 1982, at 55, available at http://www.mises.org/rothbard/lawproperty.pdf (setting forth a set of libertarian principles by which to reconstruct the law). 


\section{APPENDIX A}

The following are the results of the authors' survey of attorney fee shift provisions in wage payment and collection statutes in the United States. ${ }^{138}$

\begin{tabular}{|c|c|c|c|}
\hline State & $\begin{array}{l}\text { Primary } \\
\text { Wage and } \\
\text { Hour Statute } \\
\end{array}$ & $\begin{array}{l}\text { Fee } \\
\text { Shift? }\end{array}$ & Type of Shift \\
\hline Alabama & None & N/A & N/A \\
\hline Alaska & $\begin{array}{l}\text { Alaska Wage } \\
\text { and Hour Law }\end{array}$ & Yes & $\begin{array}{l}\text { Modified Indemnity, }{ }^{139} \text { in which } \\
\text { employees are liable for fees only } \\
\text { for bad faith claims }\end{array}$ \\
\hline Arizona & $\begin{array}{l}\text { Arizona Wage } \\
\text { Law }\end{array}$ & Yes & $\begin{array}{l}\text { Under a separate statute, Arizona } \\
\text { courts may award a successful } \\
\text { party in a contract (express or } \\
\text { implied) action its attorney } \\
\text { fees }{ }^{141}\end{array}$ \\
\hline Arkansas & $\begin{array}{l}\text { Arkansas } \\
\text { Minimum } \\
\text { Wage Act }\end{array}$ & Yes & One-Way, Plaintiff-Friendly ${ }^{142}$ \\
\hline California & $\begin{array}{l}\text { California } \\
\text { Labor Code; } \\
\text { Wage Orders } \\
\text { promulgated } \\
\text { by the } \\
\text { Industrial } \\
\text { Welfare } \\
\text { Commission }\end{array}$ & Yes & $\begin{array}{l}\text { One-Way, Plaintiff-Friendly, in } \\
\text { which employees are liable for } \\
\text { fees only for bad faith claims }{ }^{143}\end{array}$ \\
\hline
\end{tabular}

138. In researching the fee shift provisions in these various wage payment statutes, the authors relied heavily on ABA SECTION OF LABOR \& EMP'T LAW, WAGE AND HOUR LAWS: A STATE-BYSTATE SURVEY (Gregory K. McGillivary ed., 2d ed. 2010 \& Supp. 2013).

139. Alaska has adopted the English-style indemnity rule in which the prevailing party in a civil case is awarded its attorney fees. ALA. R. CIV. P. 82(a).

140. ALASKA STAT. $\$ 23.10 .110(f)(2014)$.

141. ARIZ. ReV. STAT. § 12-341.01(A) (2013).

142. ARK. CODE ANN. § 11-4-218(a)(1)(B)(ii) (2006).

143. CAL. LAB. CODE $§ 218.5$ (a) (2010). 


\begin{tabular}{|c|c|c|c|}
\hline Colorado & $\begin{array}{l}\text { Colorado } \\
\text { Wage Claim } \\
\text { Act }\end{array}$ & Yes & $\begin{array}{l}\text { Modified Indemnity, in which the } \\
\text { employee recovers fees if she } \\
\text { ultimately recovers a greater } \\
\text { amount in wages than the amount } \\
\text { tendered by the employer; if, } \\
\text { however, the employee recovers } \\
\text { less than the amount tendered, the } \\
\text { employer is entitled to fees }\end{array}$ \\
\hline Connecticut & $\begin{array}{l}\text { General } \\
\text { Statutes } \$ \$ 31- \\
71 a \text {, to } 31-71 i\end{array}$ & Yes & $\begin{array}{l}\text { One-Way, Plaintiff-Friendly, } \\
\text { in which courts require evidence } \\
\text { of bad faith, arbitrariness, or } \\
\text { unreasonableness on the part of } \\
\text { the defendant }\end{array}$ \\
\hline Delaware & $\begin{array}{l}\text { Wage } \\
\text { Payment and } \\
\text { Collection Act }\end{array}$ & Yes & One-Way, Plaintiff-Friendly ${ }^{147}$ \\
\hline $\begin{array}{l}\text { District of } \\
\text { Columbia }\end{array}$ & $\begin{array}{l}\text { Wage } \\
\text { Payment and } \\
\text { Collection } \\
\text { Law (Wage } \\
\text { Payment Act) }\end{array}$ & Yes & One-Way, Plaintiff-Friendly ${ }^{148}$ \\
\hline Florida & None & Yes & $\begin{array}{l}\text { Indemnity under a statute } \\
\text { authorizing attorney fees for the } \\
\text { "prevailing party" in "an action } \\
\text { for unpaid wages" } 149\end{array}$ \\
\hline Georgia & $\begin{array}{l}\text { GA. CODE } \\
\text { ANN. } \S 34-7-2\end{array}$ & No & N/A \\
\hline Hawaii & $\begin{array}{l}\text { Payment of } \\
\text { Wages and } \\
\text { Compensation } \\
\text { Law }\end{array}$ & Yes & $\begin{array}{l}\text { One-Way, Plaintiff-Friendly } \\
\text { (mandatory) })^{150}\end{array}$ \\
\hline
\end{tabular}

\footnotetext{
144. Colo. Rev. Stat. ANN. § 8-4-110(1) (West 2014).

145. Conn. Gen. Stat. § 31-72 (West 2014).

146. Ravetto v. Triton Thalassic Techs., Inc., 941 A.2d 309, 316-17 (Conn. 2008).

147. 19 Del. CoDE. ANN. § 1113(c) (West 2014).

148. D.C. CODE $\S 32-1012$ (c) (2013).

149. FLA. STAT. § 448.08 (West 2014).

150. HAW. REV. STAT. § 388-11(c) (West 2014).
} 


\begin{tabular}{|c|c|c|c|}
\hline Idaho & $\begin{array}{l}\text { Wage } \\
\text { Payment Act }\end{array}$ & Yes & One-Way, Plaintiff-Friendly ${ }^{151}$ \\
\hline Illinois & $\begin{array}{l}\text { Illinois Wage } \\
\text { Payment and } \\
\text { Collection Act }\end{array}$ & Yes & One-Way, Plaintiff-Friendly ${ }^{152}$ \\
\hline Indiana & $\begin{array}{l}\text { Indiana Wage } \\
\text { Payment } \\
\text { Statute }\end{array}$ & Yes & $\begin{array}{l}\text { One-Way, Plaintiff-Friendly } \\
\text { (mandatory) }\end{array}$ \\
\hline Iowa & $\begin{array}{l}\text { Wage } \\
\text { Payment } \\
\text { Collection Act }\end{array}$ & Yes & One-Way, Plaintiff-Friendly ${ }^{154}$ \\
\hline Kansas & $\begin{array}{l}\text { Kansas Wage } \\
\text { Payment Act }\end{array}$ & No & N/A \\
\hline Kentucky & $\begin{array}{l}\text { Kentucky } \\
\text { Revised } \\
\text { Statutes, } \\
\text { Chapter } 337 \\
\end{array}$ & Yes & One-Way, Plaintiff-Friendly ${ }^{155}$ \\
\hline Louisiana & $\begin{array}{l}\text { Louisiana } \\
\text { Wage } \\
\text { Payment Act }\end{array}$ & Yes & One-Way, Plaintiff-Friendly ${ }^{156}$ \\
\hline Maine & $\begin{array}{l}\text { Maine } \\
\text { Employment } \\
\text { Practices Law, } \\
\text { Subchapter } 2\end{array}$ & Yes & One-Way, Plaintiff-Friendly ${ }^{157}$ \\
\hline Maryland & $\begin{array}{l}\text { Maryland } \\
\text { Wage } \\
\text { Payment and } \\
\text { Collection } \\
\text { Law }\end{array}$ & Yes & $\begin{array}{l}\text { Modified One-Way, Plaintiff- } \\
\text { Friendly, in which the employee } \\
\text { may recover fees only if the } \\
\text { employer's violation of the law } \\
\text { was not a result of a "bona fide } \\
\text { dispute" "158 }\end{array}$ \\
\hline
\end{tabular}

151. IDAHO CODE $§ 45-615$ (2) (West 2014).

152. 820 Ill. COMP. Stat. 115/14(a) (2014). Fees are also recoverable by employees in actions for owed wages under the Illinois Attorney's Fees in Wage Actions Act, 705 Ill. Comp. STAT. 225/1 (West 2014).

153. IND. CODE ANN. § 22-2-5-2 (West 2014).

154. IOWA CoDE $\S \S 91 \mathrm{~A} .10(3), 91 \mathrm{~A} .8$ (West 2014).

155. Ky. Rev. Stat. AnN. § 337.385(1) (2013); Singleton v. Bravo Dev., Inc., No. 2006-CA002163-MR, 2007 WL 2741945 (Ky. Ct. App. Sept. 21, 2007).

156. La. ReV. Stat. § 23:231(F) (West 2013).

157. 26 ME. Rev. Stat. ANN. $§$ 626-A, 670 (effective Aug. 2014).

158. MD. CODE ANN. LAB \& EMPL. § 3-507.2(b) (2010). 


\begin{tabular}{|l|l|l|l|}
\hline Massachusetts & $\begin{array}{l}\text { Massachusetts } \\
\text { General Laws, } \\
\text { chapter 149, § } \\
148\end{array}$ & Yes & One-Way, Plaintiff-Friendly \\
\hline Michigan & $\begin{array}{l}\text { Payment of } \\
\text { Wages and } \\
\text { Fringe } \\
\text { Benefits Act }\end{array}$ & Yes & $\begin{array}{l}\text { Indemnity (applies only to } \\
\text { commissioned salespersons' } \\
\text { claims for commissions) }\end{array}$ \\
\hline Minnesota & $\begin{array}{l}\text { Minnesota } \\
\text { Statutes, } \\
\text { Chapter } 181^{161}\end{array}$ & Yes & One-Way, Plaintiff-Friendly ${ }^{162}$ \\
\hline Mississippi & None & N/A & N/A \\
\hline Missouri & $\begin{array}{l}\text { Missouri } \\
\text { Revised } \\
\text { Statutes § } \\
\text { 290.080 }\end{array}$ & No & N/A \\
\hline Montana & $\begin{array}{l}\text { Montana } \\
\text { Code, Title 39, } \\
\text { Chapter 3, Part } \\
2^{164}\end{array}$ & Yes & $\begin{array}{l}\text { Modified Indemnity, in which the } \\
\text { employee, if successful, must be } \\
\text { awarded a reasonable fee, but in } \\
\text { which the employer, if } \\
\text { successful, may recover a fee }\end{array}$ \\
\hline Nebraska & $\begin{array}{l}\text { Wage } \\
\text { Payment and } \\
\text { Collection Act }\end{array}$ & $\begin{array}{l}\text { One-Way, Plaintiff-Friendly } \\
\text { (mandatory) }\end{array}$ \\
\hline
\end{tabular}

159. MASS. GEN. LAWS ch. 149, $§ 150$ (2008).

160. Мich. COMP. LaWs $§ 600.2961(6)$ (West 2014); Peters v. Gunnell, Inc., 655 N.W.2d 582, 589-91 (Mich. Ct. App. 2002).

161. The wage payment requirements are set forth in MinN. STAT. $\S ~ 181.01$ to $181.171,181.55$ to 181.58 , and 181.79 (West 2014).

162. MinN. STAT. $§ 181.171$, subd. 3 (West 2014).

163. Mo. Rev. StAT. $\S 290.080$ (West 2012). Under $\S 290.080$ it is a misdemeanor to fail to pay wages at least twice per month. Id.

164. Mont. CODE ANN. § 39-3-204 (2009).

165. Mont. Code ANN. § 39-3-214 (2009); Ramsey v. Yellowstone Neurosurgical Assocs., P.C., 125 P.3d 1091, II 28 (Mont. 2005).

166. NeB. Rev. Stat. § 48-1231(1) (2014). The amount of the fee "shall not be less than twenty-five percent of the unpaid wages." Id. 


\begin{tabular}{|c|c|c|c|}
\hline Nevada & $\begin{array}{l}\text { Nevada } \\
\text { Revised } \\
\text { Statutes, Title } \\
53 \text {, Chapter } \\
608\end{array}$ & Yes & $\begin{array}{l}\text { One-Way, Plaintiff-Friendly }{ }^{167} \\
\text { (mandatory) }\end{array}$ \\
\hline $\begin{array}{l}\text { New } \\
\text { Hampshire }\end{array}$ & $\begin{array}{l}\text { New } \\
\text { Hampshire } \\
\text { Revised } \\
\text { Statutes, Title } \\
\text { XXIII, } \\
\text { Chapter 275 }\end{array}$ & Yes & One-Way, Plaintiff-Friendly ${ }^{168}$ \\
\hline New Jersey & $\begin{array}{l}\text { New Jersey } \\
\text { Wage } \\
\text { Payment Law }\end{array}$ & $\mathrm{No}^{169}$ & N/A \\
\hline New Mexico & $\begin{array}{l}\text { New Mexico } \\
\text { Statutes } \\
\text { Annotated, } \\
\text { Chapter 50, } \\
\text { Article } 1 \\
\end{array}$ & Yes & $\begin{array}{l}\text { One-Way, Plaintiff-Friendly } \\
\text { (mandatory) }\end{array}$ \\
\hline New York & $\begin{array}{l}\text { New York } \\
\text { Labor Law }\end{array}$ & Yes & $\begin{array}{l}\text { One-Way, Plaintiff-Friendly }{ }^{171} \\
\text { (mandatory) }\end{array}$ \\
\hline $\begin{array}{l}\text { North } \\
\text { Carolina }\end{array}$ & $\begin{array}{l}\text { North Carolina } \\
\text { Wage and } \\
\text { Hour Act }\end{array}$ & Yes & $\begin{array}{l}\text { One-Way, Plaintiff-Friendly, in } \\
\text { which the employer may recover } \\
\text { fees if the court deems the } \\
\text { employee's claim to be } \\
\text { frivolous }{ }^{172}\end{array}$ \\
\hline North Dakota & $\begin{array}{l}\text { North Dakota } \\
\text { Century Code, } \\
\text { Chapter } 34- \\
14^{173}\end{array}$ & No & N/A \\
\hline
\end{tabular}

167. NEV. REV. STAT. $\$ 608.140$ (West 2013).

168. N.H. REV. STAT. § 275:53 (West 2014).

169. Ryba v. Beynon Sports Servs., Inc., No. A-1536-09T3, 2010 WL 4811900, at *6 (N.J. App. Div. Nov. 29, 2010).

170. N.M. STAT. ANN. § 50-4-26(E) (2013).

171. N.Y LAB. LAW § 198(1) \& (1-a) (2011).

172. N.C. GEN. STAT. §95-25.22(d) (West 2013); Rice v. Danas, Inc., 514 S.E.2d 97 (N.C. Ct. App. 1999).

173. N.D. CENT. CODE § 34-14-09 (West 2013). 


\begin{tabular}{|c|c|c|c|}
\hline Ohio & None & N/A & N/A \\
\hline Oklahoma & $\begin{array}{l}\text { Oklahoma } \\
\text { Statutes, Title } \\
40\end{array}$ & Yes & One-Way, Plaintiff-Friendly ${ }^{174}$ \\
\hline Oregon & $\begin{array}{l}\text { Oregon } \\
\text { Revised } \\
\text { Statutes, } \\
\text { Chapter } 652^{175}\end{array}$ & Yes & $\begin{array}{l}\text { One-Way, Plaintiff-Friendly, in } \\
\text { which the employer may recover } \\
\text { fees if the court deems the } \\
\text { employee's claim to be } \\
\text { frivolous }\end{array}$ \\
\hline Pennsylvania & $\begin{array}{l}\text { Pennsylvania } \\
\text { Wage } \\
\text { Payment and } \\
\text { Collection } \\
\text { Law }\end{array}$ & Yes & $\begin{array}{l}\text { One-Way, Plaintiff-Friendly }{ }^{177} \\
\text { (mandatory) }\end{array}$ \\
\hline Rhode Island & $\begin{array}{l}\text { Rhode Island } \\
\text { Payment of } \\
\text { Wages Act }\end{array}$ & Yes & One-Way, Plaintiff-Friendly ${ }^{178}$ \\
\hline $\begin{array}{l}\text { South } \\
\text { Carolina }\end{array}$ & $\begin{array}{l}\text { Payment of } \\
\text { Wages Act }\end{array}$ & Yes & $\begin{array}{l}\text { One-Way, Plaintiff-Friendly, in } \\
\text { which the employee may recover } \\
\text { fees only when the employer did } \\
\text { not have a "bona fide dispute", }\end{array}$ \\
\hline South Dakota & $\begin{array}{l}\text { South Dakota } \\
\text { Codified } \\
\text { Laws, Chapter } \\
60-11\end{array}$ & $\mathrm{No}^{180}$ & N/A \\
\hline Tennessee & $\begin{array}{l}\text { Tennessee } \\
\text { Wage } \\
\text { Regulations } \\
\text { Act }\end{array}$ & Yes & $\begin{array}{l}\text { One-Way, Plaintiff-Friendly }{ }^{181} \\
\text { (mandatory) }\end{array}$ \\
\hline
\end{tabular}

174. OKLA. STAT. tit. 40, § 165.9(B) (West 2014).

175. OR. REV. STAT. $\S \S 652.110$ to 652.445 (West 2014).

176. Id. $\S 652.230(2)$.

177. 43 Pa. STAT. AnN. § 260.9a(f) (West 2014).

178. R.I. GEN. LAWS $§ 28-14-19.2$ (a) (2012).

179. S.C. Code ANN. §41-10-80-(C) (West 2013); O’Neal v. Intermedical Hosp. of S.C., 585 S.E.2d 526, 532 (S.C. Ct. App. 2003).

180. See S.D. CodifIED LAWS $\S 60-11-17$ (2011) (providing a private right of action for an employer's breach of an obligation to pay wages but not providing for an attorney fee shift).

181. Tenn. Code. ANN. §50-2-204(b) (West 2014). 


\begin{tabular}{|l|l|l|l|}
\hline Texas & $\begin{array}{l}\text { Texas Payday } \\
\text { Law }\end{array}$ & Yes $^{182}$ & One-Way, Plaintiff-Friendly \\
\hline Utah & $\begin{array}{l}\text { Utah Code } \\
\text { Annotated, } \\
\text { Title 34, } \\
\text { Chapter 40, } \\
\text { Part 2 }\end{array}$ & Yes & $\begin{array}{l}\text { One-Way, Plaintiff-Friendly } \\
\text { (mandatory) }\end{array}$ \\
\hline Vermont & $\begin{array}{l}\text { Vermont } \\
\text { Statutes } \\
\text { Annotated, } \\
\text { Title Twenty- } \\
\text { One, Chapter } \\
5\end{array}$ & Yes & $\begin{array}{l}\text { One-Way, Plaintiff-Friendly } \\
\text { (mandatory) }\end{array}$ \\
\hline Virginia & $\begin{array}{l}\text { Code of } \\
\text { Virginia, Title } \\
40.1^{187}\end{array}$ & No & $\begin{array}{l}\text { Virginia provides no fee shift for } \\
\text { a private action for wages, but } \\
\text { does provide a fee shift in favor } \\
\text { of the Virginia Department of } \\
\text { Labor and Industry in collection } \\
\text { actions. }\end{array}$ \\
\hline 188
\end{tabular}

182. While there is no fee shift for a private party under the Texas Payday Law, attorney fees are available for claims of breach of contract, quantum meruit, and promissory estoppel under TEX. CIV. PRAC. \& REM. $\S 38.001$ and 38.002 (West 2013).

183. See Tex. Civ. Prac. \& REM. $\S 38.001$ and 38.002 (West 2013) (providing for fee shift for successful contract claims).

184. UTAH CODE ANN. § 34-40-205 (2013).

185. UTAH CODE ANN. § 34-27-1 (West 2013).

186. VT. STAT. ANN. tit. 21, $\$ 347$ (West 2013).

187. Enforcement of Virginia's wage payment laws is entirely administrative. There is no private cause of action for unpaid wages.

188. VA. CODE ANN. $\$ 40.1-29$ (F) (2009).

189. WASH. REV. CODE. § 49.48 .030 (2010). Interestingly, Washington's statutory fee shift operates like an offer of judgment in that it rewards fees only if the amount of recovery is greater than the amount admitted by the employer to be owing. Id.

190. W. VA. CODE $§ 21-5-12$ (b) (West 2014). 


\begin{tabular}{|l|l|l|l|}
\hline Wisconsin & $\begin{array}{l}\text { Wisconsin } \\
\text { Statutes, } \\
\text { Chapter 109 }\end{array}$ & Yes & One-Way, Plaintiff-Friendly ${ }^{191}$ \\
\hline Wyoming & $\begin{array}{l}\text { Wyoming } \\
\text { Statutes } \\
\text { Annotated, } \\
\text { Chapter 4 }\end{array}$ & Yes & $\begin{array}{l}\text { One-Way, Plaintiff-Friendly }{ }^{192} \\
\text { (mandatory) }\end{array}$ \\
\hline
\end{tabular}

191. WIS. STAT. § 109.03(6) (2011).

192. WYo. STAT. ANN. § 27-4-104(b) (West 2013). 